\title{
TINGKAT SELF EFFICACY BERDASARKAN JENIS KELAMIN DAN KELAS PADA PESERTA DIDIK PEMINATAN ILMU-ILMU SOSIAL SMA NEGERI 5 JEMBER
}

\section{Analysis of Self efficacy Level Based on Gender and Grade of Social Studies Student SMA Negeri 5 Jember}

\author{
Siswo Suryono \\ SMA Negeri 5 Jember \\ E-mail:siswosur@gmail.com
}

\begin{abstract}
Abstrak
Paradigma pembelajaran saat ini mengarah pada teori konstruktivis yang mengharuskan peserta didik untuk memiliki kepercayaan diri memadai. Self efficacy menjadi salah satu karakteristik pembelajaran yang ideal dalam pelajaran. Penelitian sebelumnya telah menemukan bahwa self efficacy memiliki hubungan positif dengan hasil belajar. Tujuan dari penelitian ini adalah untuk menganalisis tingkat self efficacy berdasarkan jenis kelamin dan kelas pada peserta didik peminatan ilmu-ilmu sosial SMA Negeri 5 Jember. Sampel melibatkan 103 peserta didik kelas X, kelas XI, dan kelas XII peminatan IPS di SMA Negeri 5 Jember. Analisis data yang digunakan dalam penelitian ini adalah two-way Multivariate Analysis of Variance (MANOVA) dengan bantuan program SPSS 23 for windows. Hasil analisis data menunjukkan bahwa terdapat perbedaan tingkat self efficacy yang signifikan berdasarkan jenis kelamin dengan nilai signifikansi 0,000. Peserta didik perempuan mendapat skor self efficacy yang lebih tinggi daripada peserta didik laki-laki. Hasil penelitian juga menunjukkan bahwa ada perbedaan yang signifikan dalam tingkat self efficacy berdasarkan kelas dengan nilai signifikansi 0,000. Peserta didik di kelas yang lebih rendah mendapatkan skor self efficacy yang lebih tinggi daripada
\end{abstract}


peserta didik di kelas yang lebih tinggi. Pendidik diharapkan mampu melakukan rencana pembelajaran yang tepat dengan memperhatikan perbedaan tingkat self efficacy peserta didik.

Kata Kunci: Self efficacy, jenis kelamin, kelas

\section{PENDAHULUAN}

Sistem pembelajaraan saat ini mengarah pada pembelajaran yang berpusat pada peserta didik atau sering disebut dengan student centered learning (Judi \& Sahari, 2013). Artinya pemenuhan kompetensi peserta didik dalam proses pembelajaran tidak lagi menjadikan pendidik sebagai pusatnya. Kurikulum pendidikan terbaru yang diterapkan di Indonesia yaitu kurikulum 2013 menjadikan student centered learning sebagai penyempurnaan pola pikir pembelajaran.

Belum optimalnya penerapan student centered learning menjadi salah satu permasalahan dalam pembelajaran saat ini. Menurut Umamah (2014) pendidik terkendala dalam proses perancangan desain pembelajaran, khususnya dalam penyusunan instrumen penilaian dan penerapan pendekatan saintifik. Kesulitan tersebut membuat pembelajaran di beberapa sekolah masih menggunakan paradigma lama dimana pendidik menjadi pusat dalam pemenuhan kompetensi peserta didik (Subakti, 2010).

Penerapan student centered learning salah satunya dapat diwujudkan dalam bentuk keterlibatan peserta didik dalam proses pembelajaran atau disebut self efficacy. Self efficacy merupakan salah satu isu yang cukup populer dalam dunia pendidikan dewasa ini (Conner, 2016; Skinner, Kindermann, Connell, \& Wellborn, 2009). Menjadi populer dikarenakan self efficacy memiliki hubungan yang positif terhadap hasil belajar peserta didik dan kualitas pendidikan (Coates, 2010; Dalun Zhang, Hsu, Kwok, Benz, \& Bowman-Perrott, 2011; Dotterer \& Lowe, 2011; Fredricks et al., 2004). Menurut Fredricks, Blumenfeld, dan Paris, (2004) penelitian selama 10 tahun terakhir membuktikan bahwa self efficacy sebagai faktor penting bagi keberhasilan belajar peserta didik dan juga berkaitan dengan resiko putus sekolah.

Penelitian ini fokus pada permasalahan yang berkembang pada peserta didik peminatan ilmu-ilmu sosial di SMA Negeri 5 Jember. Berdasarkan data hasil ujian nasional berbasis komputer (UNBK) tahun 2017 hingga 2018, nilai rata-rata program peminatan IPS belum mencapai target Kriteria Ketuntasan Minimal (KKM) Ujian Nasional yang ditetapkan Badan 
Standar Nasional Pendidikan sebesar 55,0. Data tahun 2017 menunjukkan nilai rata-rata program IPS sebesar 48,13. Pada tahun berikutnya, nilai rata-rata program IPS menunjukkan angka 50,3. Artinya, selama kurun waktu satu tahun hanya terjadi peningkatan sebesar 2,17. Hal ini menjadi alasan empiris bagi peneliti untuk mengkaji tingkat self efficacy peserta didik program ilmu-ilmu sosial di SMA Negeri 5 Jember.

Berdasarkan rekomendasi dari penelitian-penelitian terdahulu, upaya untuk mengetahui tingkat self efficacy perlu dilakukan. Terutama bagi seluruh komponen yang terlibat dalam bidang pendidikan. Menurut Olson dan Peterson (2015) dengan mengetahui sejauh mana tingkat self efficacy bagi pihak sekolah dapat membuat program-program yang memfasilitasi peserta didik untuk lebih meningkatkan motivasi, hubungan dengan sekolah, rasa memiliki terhadap sekolah, dan partisipasi peserta didik. Manfaat bagi pendidik dapat dijadikan sebagai pedoman evalusi kegiatan pembelajaran. Sehingga pendidik akan mengetahui apakah desain pembelajaran yang susun dan diterapkan sudah dapat membuat peserta didik berperan aktif ataukah tidak.

Self efficacy merupakan suatu istilah yang digunakan untuk mengidentifikasi keterlibatan peserta didik dalam kegiatan di lingkungan sekolah termasuk proses pembelajaran di kelas (Finn, 1989). Pendapat lain mengatakan bahwa self efficacy sebagai “multidimensional construc" yang terdiri dari tiga komponen utama yaitu behavioural, emotional, dan cognitive (Fredricks, Blumenfeld, \& Paris, 2004; Sharkey, Sukkyung, \& Schnoebelen, 2008; Zaff et al., 2011).

\section{a. Behavioural}

Behavioural merupakan komponen yang meliputi beberapa perilaku keterlibatan peserta didik yang dilakukan di sekolah maupun di dalam kelas. Menurut Hospel, Galand, dan Janosz (2016), behaviour merupakan perilaku peserta didik yang meliputi ditunjukan dengan partisipasi saat proses pembelajaran, mematuhi perintah pendidik dan peraturan sekolah, melakukan kegiatan yang tidak berguna, perilaku mengaganggu, dan membolos.

\section{b. Emotional}

Emotional berkaitan dengan perasaan di dalam diri peserta didik yang bersifat internal dan biasanya sulit untuk diamati (Ansong, Okumu, Bowen, Walker, \& Eisensmith, 2017). Perasaan ini meliputi rasa minat belajar, kebosanan, kebahagiaan, kesedihan, dan kecemasan.

Emotional juga mencakup rasa memiliki dan menjadi bagian dari sekolah, dan memiliki hubungan baik dengan pendidik dan peserta didik lain (Fredricks, Blumenfied, \& Paris, 2004). 
Hubungan peserta didik dengan pendidik juga mempengaruhi emotional apakah peserta didik merasa nyaman, bahagia, mempunyai antusias yang tinggi ataukah sebaliknya (Conner, 2016).

\section{c. Cognitive}

Cognitive mengacu kepada fleksibilitas peserta didik dalam pemecahan masalah, kecenderungan untuk bekerja keras, dan memiliki cara positif dalam menghadapi kegagalan (Connell \& Wellborn, 1991 dalam Fredricks, Blumenfied, \& Paris, 2004). Peserta didik dengan keterlibatan kognitif tinggi akan memiliki keinginan untuk terlibat dalam proses pembelajaran dan berusaha untuk menguasai materi dan keterampilan tertentu (Fredricks, Blumenfied, \& Paris, 2004).

Terdapat beberapa faktor yang dapat mempengaruhi tinggi atau rendahnya tingkat self efficacy berdasarkan pendapat beberapa ahli. Menurut Fredricks, Blumenfied, dan Paris (2004) terdapat tiga faktor yang mempengaruhi self efficacy, yaitu (1) school-size, (2) classroom context, dan (3) individual needs. Selaian itu, karakteristik peserta didik juga dapat memberikan dampak terhadap tingkat self efficacy (Amir et al., 2014; Shernoff, Csikszentmihalyi, Shneider, \& Shernoff, 2003).

Penelitian-penelitian sebelumnya mengungkapkan bahwa tingkat self efficacy peserta didik laki-laki dan perempuan berbeda secara signifikan (Fernández-Zabala, Goñi, Camino, \& Zulaika, 2015; Teoh, Abdullah, Roslan, \& Daud, 2013; Lam et al., 2012). Peserta didik perempuan memiliki tingkat self efficacy yang lebih tinggi. Peserta didik perempuan sedikit melakukan perilaku yang tidak berguna dan menggangu peserta didik lain dibandingkan dengan peserta didik laki-laki. Peserta didik perempuan juga memiliki ketekunan yang lebih tinggi (Kenney-Benson, Pomerantz, Ryan, \& Patrick, 2006). Pendapat lain menyebutkan bahwa hasil tersebut tidak selalu terjadi di berbagai negara. Menurut hasil penelitian dari King (2016) ditemukan bahwa tidak terdapat perbedaan yang signifikan tingkat self efficacy antara peserta didik perempuan dan peserta didik laki-laki di Filipina.

Tingkatan Kelas peserta didik dapat menunjukkan usia dan lama masa belajar peserta didik. Penelitian-penelitian sebelumnya menemukan bahwa peserta didik dengan usia muda dan usia lebih tua memiliki perbedaan tingkat self efficacy yang signifika (Amir, Saleha, Mohd Jelas, Ahmad, \& Hutkemri, 2014; Fernández-Zabala, Goñi, Camino, \& Zulaika, 2015). Peserta didik pada kelas yang lebih rendah dengan usia muda cenderung memiliki tingkat self efficacy tinggi. Menurut Amir, Saleha, Mohd Jelas, Ahmad, dan Hutkemri, (2014) seiring dengan bertambah usia peserta didik, mereka merasa proses pembelajaran tidak lagi menyenangkan. 
Peneliti tertarik untuk mengkaji self efficacy berdasarkan karakteristik peserta didik yang meliputi jenis kelamin dan kelas. Penelitian-penelitian mengenai self efficacy yang ditemukan di Indonesia banyak dilakukan untuk mengetahui hubungannya dengan variabel-variabel lain atau hanya sebatas studi deskriptif dengan sampel yang kecil.

Berdasarkan pemaparan di atas, tujuan penelitian ini adalah: (1) menganalisis tingkat self efficacy peserta didik peminatan ilmu-ilmu sosial SMA Negeri 5 Jember, (2) menganalisis perbandingan tingkat self efficacy berdasarkan jenis kelamin dan kelas pada peserta didik peminatan ilmu-ilmu sosial SMA Negeri 5 Jember.

\section{METODE PENELITIAN}

Jenis penelitian yang digunakan adalah deskriptif komparasi. Penelitian ini membandingkan variabel independen yaitu tingkat self efficacy berdasarkan dua variabel dependen yaitu jenis kelamin dan kelas. Jenis kelamin terdiri dari peserta didik laki-laki dan perempuan, sedangkan kelas terdiri dari peserta didik kelas X, kelas XI, dan kelas XII penjurusan IPS.

\section{Sampel Penelitian}

Teknik pengambilan sampel yang digunakan dalam penelitian ini adalah teknik random sampling. Sampel yang dilibatkan adalah peserta didik peminatan ilmu-ilmu sosial SMA Negeri 5 Jember yang berasal dari 3 kelas berbeda.

Tabel 1. Sampel Penelitian

No. Karakteristik Peserta $\mathrm{N}$

Didik

\begin{tabular}{lllc}
\hline 1. & Jenis & Laki-laki & 78 \\
& Kelamin & & \\
\cline { 3 - 3 } & & Perempuan & 25 \\
\hline 2. & Tingkat & Kelas X & 36 \\
\cline { 3 - 3 } & Kelas & Kelas XI & 34 \\
& & & \\
\cline { 3 - 3 } & & Kelas XII & 33
\end{tabular}




\section{Instrumen Penelitian}

Instrumen penelitian yang digunakan mengadaptasi instrumen penelitian yang dikembangkan oleh Blumenfied dan Fredricks (2005) yaitu School Measure (SEM)MacArthur. Pernyataan yang terdapat dalam School Measure (SEM)-MacArthur berjumlah 45 butir.

\section{Analisis Data}

Analisis data penelitian ini menggunakan bantuan program SPSS 23 for Windows. Sebelum melakukan analisis data, peneliti melakukan uji persyaratan analisis yang meliputi uji normalitas dan homogenitas.

\section{a. Uji Normalitas}

Penghitungan uji normalitas pada penelitian ini menggunakan statistik KolmogorovSmirnov.

Tabel 2. Uji Normalitas Berdasarkan

Jenis Kelamin

\begin{tabular}{ccccc}
\hline \multirow{2}{*}{$\begin{array}{l}\text { Jenis } \\
\text { Kelamin }\end{array}$} & \multicolumn{3}{c}{ Kolmogorov-Smirnov $^{\mathrm{a}}$} \\
\cline { 2 - 5 } & Statistic & df & Sig. \\
\hline Total & Laki-laki & .053 & 102 & $.200^{*}$ \\
Skor & & & & \\
\cline { 2 - 5 } & Perempuan & .050 & 102 & $.200^{*}$
\end{tabular}

Nilai signifikansi keduanya lebih dari 0.05 maka skor self efficacy berdasarkan jenis kelamin berdistribusi normal.

Tabel 3. Uji Normalitas Berdasarkan Kelas

\begin{tabular}{|c|c|c|c|c|}
\hline & & Kolm & rov-S & nov $^{a}$ \\
\hline & Kelas & Statistic & $\mathrm{df}$ & Sig. \\
\hline Total & X & .055 & 102 & $.200^{*}$ \\
\hline Skor & XI & .070 & 102 & $.200^{*}$ \\
\hline & XII & .062 & 102 & $.200^{*}$ \\
\hline
\end{tabular}


Nilai signifikansi kelas X, kelas XI, dan kelas XII lebih dari 0.05, maka skor self efficacy berdasarkan kelas berdistribusi normal.

\section{b. Uji Homogenitas}

Hasil uji homogenitas pada statistik MANOVA dapat dilihat pada tabel Box's Test of Equality of Covariance Matrices.

Tabel 4. Box's Test of Equality of Covariance Matrices

\begin{tabular}{lr}
\hline Box's M & 58.014 \\
F & 1.891 \\
df1 & 30 \\
df2 & 259510.347 \\
Sig. & .002 \\
\hline
\end{tabular}

Tabel Box's Test of Equality of Covariance Matrices di atas menunjukan nilai signifikansi sebesar 0.002. Pallant (2010:294) dan Ho (2014:121) merekomendasikan nilai signifikansi untuk Box's Test of Equality of Covariance Matrices adalah lebih dari 0.001. Jadi nilai signifikansi yang diperoleh tidak melanggar asumsi homogenitas matrik varian-kovarian.

Selanjutnya dilakukan analisis data dengan teknik two-way Multivariate Analysis of Variance (MANOVA). Teknik tersebut digunakan karena dalam penelitian ini terdapat beberapa variabel independen yang terdiri dari jenis kelamin (laki-laki dan perempuan) dan kelas (kelas X, XI, dan XII).

\section{HASIL DAN PEMBAHASAN}

Berikut ini dipaparkan mengenai hasil hasil penelitian yang meliputi deskriptif statistik skor self efficacy dari sampel secara keseluruhan dan berdasarkan jenis kelamin dan kelas. Selain itu juga dipaparkan mengenai hasil uji hipotesis penelitian.

\section{Deskriptif Statistik Self efficacy}

Hasil deskriptif statistik self efficacy menunjukkan nilai mean peserta didik SMA Negeri 5 Jember adalah 3.5626, dengan standar deviasi 0.50858. Deskriptif statistik self efficacy berdasarkan jenis kelamin menunjukkan nilai mean peserta didik laki-laki sebesar 3.4626 dan 
nilai mean peserta didik perempuan sebesar 3.6625. Standar deviasi peserta didik laki-laki 0.5259 dan peserta didik perempuan 0.4713. Deskriptif statistik self efficacy berdasarkan kelas menunjukkan nilai mean self efficacy peserta didik kelas X sebesar 3.7150, peserta didik kelas XI sebesar 3.5340, peserta didik kelas XII sebesar 3.4387. Standar deviasi peserta didik kelas X 0.41741, kelas XI 0.48289, dan kelas XII 0.57727.

Tabel 5. Deskriptif Statistik

\begin{tabular}{cccc}
\hline \multirow{2}{*}{ No. } & Karakteristik & \multicolumn{2}{c}{ Self efficacy } \\
\cline { 3 - 4 } & Peserta Didik & Mean & SD \\
\hline 1. & Laki-laki & 3.4626 & 0.5259 \\
\cline { 2 - 4 } & & & \\
\cline { 2 - 4 } & Perempuan & 3.6625 & 0.4713 \\
\hline 2. & Kelas X & 3.7150 & 0.41741 \\
\cline { 2 - 3 } & & \\
\hline & Kelas XI & 3.5340 & 0.48289 \\
\cline { 2 - 3 } & & \\
\hline & Kelas XII & 3.4387 & 0.57727
\end{tabular}

Interpretasi nilai mean yang digunakan berdasarkan pendapat dari Ameer (2013) dimana terdapat tiga tingkat rentang nilai mean yaitu low, intermediate, dan high. Tingkat self efficacy peserta didik SMA Negeri 5 Jember didominasi oleh peserta didik yang berada pada tingkat intermediate dengan persentase 55,6\%. Kemudian diikuti oleh peserta didik yang berada pada tingkat high dengan persentase $43,5 \%$. Sedangkan peserta didik yang berada pada tingkat low hanya sebesar $0,8 \%$. Dapat disimpulkan bahwa tingkat self efficacy peserta didik peminatan ilmu-ilmu sosial SMA Negeri 5 Jember berada pada tingkatan intermediate.

Self efficacy adalah faktor penting bagi peserta didik untuk mencapai hasil belajar yang baik (Fredricks et al., 2004). Semakin tinggi tingkat self efficacy yang dimiliki peserta didik, maka semakin tinggi pula capaian hasil belajarnya. Bahkan tingkat self efficacy yang rendah dapat berdampak pada resiko putus sekolah. Menurut Fredricks, Blumenfied, dan Paris (2004) tingkat self efficacy dapat dipengaruhi oleh beberapa faktor yang meliputi: (1) school-size, (2) classroom context, dan (3) individual needs. Faktor-faktor tersebut memungkinkan untuk 
menjadi penyebab self efficacy peserta didik SMA Negeri 5 Jember berada pada tingkat intermediate.

Tabel 6. Tingkat Self Efficacy Peserta Didik

\begin{tabular}{cccc}
\hline No. & Rentang & Tumlah \\
& Mean & Tingkat & Sampel \\
& & & \\
\hline 1. & $1.00-2.32$ & Low & 13 \\
\hline 2. & $2.35-3.67$ & Interme. & 65 \\
\hline 3. & $3.68-5.00$ & High & 25 \\
\hline \multicolumn{3}{c}{ Jumlah } & 103 \\
& &
\end{tabular}

Berdasarkan tabel deskriptif statistik komponen self efficacy peserta didik laki-laki, behavioural memiliki nilai mean tertinggi yaitu sebesar 3.7650. Kemudian diikuti oleh emotional dengan nilai mean sebesar 3.5198 dan cognitive sebesar 3.1031. Artinya peserta didik laki-laki memiliki tingkat behavioural yang lebih tinggi daripada emotional dan cognitive .

Tabel 7. Deskriptif Statistik Komponen Self efficacy Peserta Didik Laki-laki

\begin{tabular}{clcc}
\hline No. & Komponen & Mean & SD \\
\hline 1. & Behavioural & 3.7650 & 0.59726 \\
\hline 2. & Emotional & 3.5198 & 0.74541 \\
\hline 3. & Cognitive & 3.1031 & 0.71358
\end{tabular}

Deskriptif statistik komponen self efficacy peserta didik perempuan menunjukkan behavioural menjadi komponen yang memperoleh nilai mean paling tinggi yaitu sebesar 3.9616. Komponen emotional memperoleh nilai mean sebesar 3.5556, dan komponen 
cognitive memperoleh nilai mean sebesar 3.4703. Artinya peserta didik perempuan juga memiliki tingkat behavioural lebih tinggi daripada emotional dan cognitive.

Tabel 8. Deskriptif Statistik Komponen Self efficacy Peserta Didik Perempuan

\begin{tabular}{clcc}
\hline No. & Komponen & Mean & SD \\
\hline 1. & Behavioural & 3.9616 & 0.56878 \\
\hline 2. & Emotional & 3.5556 & 0.55723 \\
\hline 3. & Cognitive & 3.4703 & 0.66023 \\
\hline
\end{tabular}

Berdasarkan deskriptif statistik komponen self efficacy peserta didik kelas X, komponen yang memperoleh nilai mean tertinggi adalah behavioural yaitu sebesar 4.0721. Selanjutnya nilai mean dari emotional sebesar 3.7302 dan cognitive sebesar 3.3877.

Tabel 9. Deskriptif Statistik Komponen Self efficacy Peserta Didik Kelas X

\begin{tabular}{clcc}
\hline No. & Komponen & Mean & SD \\
\hline 1. & Behavioural & 4.0721 & 0.49951 \\
\hline 2. & Emotional & 3.7302 & 0.56569 \\
\hline 3. & Cognitive & 3.3877 & 0.63830 \\
\hline
\end{tabular}

Berdasarkan deskriptif statistik komponen self efficacy peserta didik kelas XI, nilai mean lebih tinggi dimiliki oleh behavioural yaitu sebesar 3.8831. Sedangkan untuk komponen emotional sebesar 3.4732 dan cognitive sebesar 3.2458.

Tabel 10. Deskriptif Statistik Komponen Self efficacy Peserta Didik Kelas XI

\begin{tabular}{clcc}
\hline No. & Komponen & Mean & SD \\
\hline 1. & Behavioural & 3.8831 & 0.53482 \\
\hline 2. & Emotional & 3.4732 & 0.61940 \\
\hline 3. & Cognitive & 3.2458 & 0.72812 \\
\hline
\end{tabular}


Deskriptif statistik komponen self efficacy peserta didik kelas XII menunjukan behavioural menjadi komponen yang memperoleh nilai mean tertinggi yaitu sebesar 3.6797. Selanjutnya nilai mean dari emotional yaitu sebesar 3.4096 dan cognitive sebesar 3.2267.

Tabel 11. Deskriptif Statistik Komponen Self efficacy Peserta Didik Kelas XII

\begin{tabular}{clcc}
\hline No. & Komponen & Mean & SD \\
\hline 1. & Behavioural & 3.6797 & 0.67489 \\
\hline 2. & Emotional & 3.4096 & 0.73627 \\
\hline 3. & Cognitive & 3.2267 & 0.75531 \\
\hline
\end{tabular}

Dapat disimpulkan bahwa peserta didik kelas X, kelas XI, dan kelas XII tinggi dalam komponen behavioural kemudan diikuti oleh emotional dan cognitive .

Tabel 12.Uji MANOVA

\begin{tabular}{lccccc}
\hline & \multicolumn{5}{c}{ Hypothes } \\
Effect & Value & $\mathrm{F}$ & is df & Error df & Sig. \\
& & & & & \\
\hline Jenis Kelamin & .917 & $10.524^{\mathrm{b}}$ & 3.000 & 348.000 & .000 \\
\hline Tingkat Kelas & .912 & $5.463^{\mathrm{b}}$ & 6.000 & 696.000 & .000 \\
\hline
\end{tabular}

Hipotesis $1\left(\mathrm{H}_{1}\right)$ tidak terdapat perbedaan yang signifikan tingkat self efficacy peserta didik laki-laki dan peserta didik perempuan. Berdasarkan uji MANOVA, diketahui nilai Wilks' Lambda adalah 0.917 dengan nilai signifikansi (Sig.) 0.000. Nilai signifikansi (Sig.) $0.000<0.05$ maka hipotesis $\mathrm{H}_{1}$ ditolak. Jadi dapat disimpulkan ada perbedaan yang signifikan tingkat self efficacy peserta didik laki-laki dan perempuan.

Perbandingan nilai mean masing-masing komponen self efficacy berdasarkan jenis kelamin, diperoleh nilai signifikansi (Sig.) behavioural peserta didik laki-laki dan perempuan adalah $0.000<0.05$, nilai signifikansi (Sig.) emotional peserta didik laki-laki dan perempuan $0.400>0.05$, dan nilai signifikansi (Sig.) cognitive peserta didik laki-laki dan perempuan $0.000<0.05$. Jadi dapat disimpulkan peserta didik laki-laki dan perempuan memiliki perbedaan yang signifikan pada komponen behavioural dan cognitive. Sedangkan untuk komponen 
emotional tidak terdapat perbedaan yang signifikan antara peserta didik laki-laki dan perempuan.

Penelitian sebelumnya mengatakan bahwa berdasarkan jenis kelamin, perbedaan yang signifikan terdapat pada komponen behavioural dan emotional. Namun pada komponen cognitive tidak ditemukan perbedaan yang signifikan (Fernández-Zabala, Goñi, Camino, \& Zulaika, 2015; Amir, Saleha, Mohd Jelas, Ahmad, \& Hutkemri, 2014).

Menurut Amir, Saleha, Mohd Jelas, Ahmad, dan Hutkemri (2014) peserta didik perempuan lebih baik dalam mengerjakan tugas, memperhatikan pendidik saat pembelajaran, mempersiapkan aktivitas belajar, dan juga memiliki hubungan yang lebih baik dengan pendidik. Menurut Teoh, Abdullah, Roslan, dan Daud (2013) peserta didik perempuan memiliki keaktifan yang lebih pada saat proses pembelajaran. Penelitian dari Kenney-Benson et al. (2006) menemukan bahwa peserta didik perempuan jarang melakukan perilaku-perilaku yang mengganggu peserta didik lain di dalam kelas. Selain itu, peserta didik perempuan memiliki ketekunan yang lebih tinggi dibandingkan dengan peserta didik laki-laki.

Rendahnya tingkat self efficacy ditandai dengan kurangnya strategi belajar yang dimiliki oleh peserta didik laki-laki (Ghazvivi dan Khajehpour, 2011). Selain itu peserta didik laki-laki juga meluangkan waktu untuk belajar lebih sedikit dibandingkan dengan peserta didik perempuan (Wagner, Schober, \& Spiel, 2008; Xu, 2006). Hubungan dengan teman sebaya juga berpengaruh terhadap tingkat self efficacy peserta didik laki-laki. Menurut King (2016) teman sebaya yang memberikan dampak negatif akan membuat peserta didik tersebut juga memiliki perilaku negatif di sekolah.

Hipotesis $2\left(\mathrm{HO}_{2}\right)$ tidak terdapat perbedaan yang signifikan tingkat self efficacy peserta didik kelas X, XI, dan XII. Berdasarkan tabel uji MANOVA, diketahui nilai Wilks' Lambda adalah 0.912 dengan nilai signifikansi (Sig.) 0.000. Nilai signifikansi (Sig.) $0.000<0.05$ maka hipotesis $\mathrm{HO}_{2}$ ditolak. Jadi dapat disimpulkan ada perbedaan yang signifikan tingkat self efficacy peserta didik kelas X, XI, dan XII.

Perbandingan nilai mean masing-masing komponen self efficacy berdasarkan kelas, diketahui nilai signifikansi (Sig.) behavioural adalah $0.000<0.05$, nilai signifikansi (Sig.) emotional $0.000<0.05$, dan nilai signifikansi (Sig.) cognitive $0.58>0.05$. Berdasarkan hasil tersebut maka dapat disimpulkan peserta didik kelas X, kelas XI, dan kelas XII memiliki perbedaan yang signifikan pada komponen behavioural dan emotional . Sedangkan untuk 
komponen cognitive tidak terdapat perbedaan yang signifikan antara peserta didik kelas $\mathrm{X}$, kelas XI, dan kelas XII.

Hasil tersebut menunjukkan perbedaan pada komponen cognitive. Penelitian sebelumnya. mengatakan bahwa berdasarkan kelas, perbedaan yang signifikan terdapat semua komponen yang meliputi behavioural dan cognitive, dan cognitive (Fernández-Zabala, Goñi, Camino, \& Zulaika, 2015; Amir, Saleha, Mohd Jelas, Ahmad, \& Hutkemri, 2014).

Dengan bertambahnya usia, peserta didik merasa aktifitas di sekolah ataupun pembelajaran dikelas sudah tidak menyenangkan lagi (Amir, Saleha, Mohd Jelas, Ahmad, \& Hutkemri, 2014). Menurut Fernández-Zabala, Goñi, Camino, dan Zulaika (2015) peserta didik dengan usia muda memiliki dukungan sosial yang baik dari lingkungannya dibandingkan dengan peserta didik usia lebih tua. Dukungan sosial yang dimaksud adalah dukungan dari orang tua dan dari pendidik di sekolah.

\section{KESIMPULAN DAN SARAN}

\section{Kesimpulan}

Berdasarkan hasil dan pembahasan penelitian yang telah diuraikan, dapat diperoleh kesimpulan sebagai berikut:

a. terdapat perbedaan yang signifikan tingkat self efficacy antara peserta didik laki-laki dan perempuan (0.000). Peserta didik perempuan memperoleh skor self efficacy yang lebih tinggi dibandingkan dengan peserta didik laki-laki. Peserta didik laki-laki dan perempuan berbeda signifikan pada komponen behavioural (0.000) dan cognitive (0.000). Sedangkan pada komponen emotional tidak ditemuakan perbedaan signifikan (0.400).

b. terdapat perbedaan yang signifikan tingkat self efficacy antara peserta didik kelas X, kelas XI, dan kelas XII (0.000). Peserta didik pada tingkat kelas yang lebih rendah memperoleh skor self efficacy yang lebih tinggi dibandingkan dengan peserta didik yang berada pada tingkat kelas lebih tinggi. Peserta didik kelas X, kelas XI, dan kelas XII berbeda siginifikan pada komponen behavioural (0.000) dan emotional (0.000). Sedangkan pada komponen cognitive tidak ditemukan perbedaan signifikan (0.58). 


\section{DAFTAR PUSTAKA}

Ansong, D., Okumu, M., Bowen, G. L., Walker, A. M., \& Eisensmith, S. R. 2017. The role of parent, classmate, and teacher support in self efficacy: Evidence from Ghana. International Journal of Educational Development, 54(March), 51-58.

Amir, R., Saleha, A., Mohd Jelas, zalizan, Ahmad, A. R., \& Hutkemri. 2014. Students ' by Age and Gender : A Cross-Sectional Study in Malaysia. Middle-East Journal of Scientific Research, 21(10), 1886-1892.

Coates, H. 2010. Development of the Australasian survey of self efficacy (AUSSE). Higher Education, 60(1), 1-17.

Conner, T. 2016. Relationships: The Key to Self efficacy. International Journal of Education and Learning, 5(1), 13-22.

Dalun Zhang, Hsu, H.-Y., Kwok, O., Benz, M., \& Bowman-Perrott, L. 2011. The Impact of Basic-Level Parent s on Student Achievement: Patterns Associated with Race/Ethnicity and Socioeconomic Status (SES). Journal of Disability Policy Studies, 22(1), 28-39.

Dotterer, A. M., \& Lowe, K. 2011. Classroom Context, School , and Academic Achievement in Early Adolescence. Journal of Youth and Adolescence, 40(12), 1649-1660.

Fernández-Zabala, A., Goñi, E., Camino, I., \& Zulaika, L. M. 2015. Family and school context in school . European Journal of Education and Psychology, 1-9.

Finn, J. D. 1989. Withdrawing from school. Review of Educational Research, 59, 117-142.

Fredricks, J. A., Blumenfeld, P. C., \& Paris, A. H. 2004. School : Potential of the Concept, State of the Evidence. Review of Educational Research, 74(1), 59-109.

Ho, R. 2014. Handbook of Univariate and Multivariate Data Analysis with IBM SPSS Second Edition. New York: CRC Press.

Judi, H. M., \& Sahari, N. 2013. Student Centered Learning in Statistics: Analysis of Systematic Review. Procedia - Social and Behavioral Sciences, 103(1996), 844-851.

King, R. B. 2016. Gender differences in motivation, and achievement are related to students' perceptions of peer - but not of parent or teacher - attitudes toward school. Learning and Individual Differences, 52, 60-71.

Olson, A. L., \& Peterson, R. L. 2015. Self efficacy, Strategy Brief. Lincoln, NE: Self efficacy Project, University of Nebraska-Lincoln and the Nebraska Department of Education.

Pallant, J. 2010. SPSS Survival Manual: A Step by Step Guide to Data Analysis Using SPSS $4^{\text {th }}$ Edition. Berkshire: The McGraw Hill.

Sanjaya, H. W. 2014. Penelitian Pendidikan: Jenis, Metode dan Prosedur. Jakarta: Kencana Prenada Media Grup.

Sharkey, J. D., You, S., \& Schnoebelen, K. 2008. Relations Among School Assets, Individual Resilience, and Self efficacy for Youth Grouped by Level of Family Functioning. Psychology in the Schools, 45(5), 402-418. 
Shernoff, D. J., Csikszentmihalyi, M., Shneider, B., \& Shernoff, E. S. 2003. Self efficacy in high school classrooms from the perspective of flow theory. School Psychology Quarterly, 18(2), 158-176.

Skinner, E. a, Kindermann, T. A., Connell, J. P., \& Wellborn, J. G. 2009. and disaffection as organizational constructs in the dynamics of motivational development. Handbook of Motivation in School, (503), 223-246.

Subakti, Y. R. 2010. Paradigma Pembelajaran Sejarah Berbasis Konstruktivisme. FKIP Universitas Sanata Dharma Yogyakarta, 24(1), 1-23.

Teoh, H. C., Abdullah, M. C., Roslan, S., \& Daud, S. 2013. An Investigation of Self efficacy in a Malaysian Public University. Procedia - Social and Behavioral Sciences, 90(InCULT 2012), 142-151.

Umamah, N. 2014. Kurikulum 2013 dan Kendala yang Dihadapi Pendidik dalam Merancang Desain Pembelajaran Sejarah. Prosiding Seminar Nasional 2014, Pembelajaran Sejarah di Tengah Perubahan.

Zaff, J. F., Kawashima-Ginsberg, K., Lin, E. S., Lamb, M., Balsano, A., \& Lerner, R. M. 2011. Developmental trajectories of civic across adolescence: Disaggregation of an integrated construct. Journal of Adolescence, 34(6), 1207-1220. 